\title{
IAMJ
}

INTERNATIONAL

AYURVEDIC

MEDICAL JOURNAL

ISSN: 2320-5091

Impact Factor: 6.719

\section{A COMPARISON OF BRIHATTRAYEE AND YOGIC DARSHANA}

\author{
Kankre Rameshwari ${ }^{1}$, Sajjanshethy M. R ${ }^{2}$, Kanolli G. $\mathbf{N}^{3}$ \\ ${ }^{1}$ P.G. Scholar, Department of Samhita Siddhanta, S.V.M Ayurvedic Medical College and Hospital, Ilkal, \\ Karnataka, India \\ ${ }^{2}$ Professor, Dept. of Samhita Siddhanta, S.V.M Ayurveda Medical College, Ilkal, Karnataka, India \\ ${ }^{3}$ Lecturer, Dept. of Samhita Siddhanta, S.V.M Ayurveda Medical College, Ilkal, Karnataka, India
}

Corresponding Author: vishwaradhe99@gmail.com

https://doi.org/10.46607/iamj1609032021

(Published online: March 2021)

Open Access

(C) International Ayurvedic Medical Journal, India 2021

Article Received: 12/02/2021 - Peer Reviewed:24/02/2021 - Accepted for Publication:06/03/2021

\section{Check for updates}

\begin{abstract}
Yoga Darshana and Ayurveda being contemporary sciences have influenced and complemented each other. The concepts of Yoga Darshana are selectively incorporated in Ayurveda to suit its objectives viz., 'Swasthya Rakshana' and 'Roga Prashamana.' Most of the concepts of yoga are accepted as such, some are modified for the medical science. Application of the concepts of yoga in conjunction with Ayurveda enhances the therapeutic application of both the contemporary systems of healing. Ayurveda provides the appropriate lifestyle recommendations for Yoga practice, as well as the background to unfold the full healing potential of all aspects of Yoga. It is important to integrate Yoga and Ayurveda in order to bring out a complete holistic healing system. Integrating Yoga with Ayurveda adds a spiritual and psychological dimension to Ayurvedic treatment modalities, without which Ayurveda tends to become a mere physical model devoid of spiritual and Vedic healing powers. Ayurveda focuses on individual' constitution or body type which is referred to as Prakriti. It is defined as expression of a person in context to morphology, physiology, behavior and relation to ecology. The application of Tattvas of Yoga Darshana in Ayurveda finds similarity in some contexts and dissimilarity in others, which are elaborated in the article and along with This Yoga Asanas according to the specific constitution of an individual is cited in this article.
\end{abstract}


Keywords: Darshana, Prakriti, Tattva, Yoga Asanas, Swasthya Rakshana, Roga Prashamana.

\section{INTRODUCTION}

The influence of Darshanas on Ayurveda is evident in classical literatures. The concepts of Yoga Darshana are selectively incorporated in Ayurveda to suit its objectives viz., 'Swasthya Rakshana'and 'Roga Prashama$n a^{l}$. Ayurveda deals with the health of the body and mind $^{3}$, while Yoga deals with health of the mind and purity of consciousness ${ }^{2}$, but in reality, they complement and embrace each other. These ancient sister Vedic sciences have been united for thousands of years for the sake of healing body, mind and consciousness. Yoga clubbed together with Ayurveda will produce positive effects on health. Both comprehensively illuminate the basic laws and principles governing life on earth. As a holistic system, Ayurveda does not generalize the principles and states that each aspect should be individualized according to the season and individual constitution to avoid any derangement of Doshas and promote or restore health ${ }^{4}$. Ayurveda and Yoga complement each other for an overall balanced and healthy lifestyle. Yoga rests upon Ayurvedic medicine for its health implications. Ayurveda rests upon Yoga for its mental and spiritual dimensions.

Analysis of concepts of Yoga Darshana and Ayurveda in relation with each other

\section{Definition of Yoga}

The definition of 'Yoga' according to Yoga Darshana is 'Yogaschittavrtti Nirodhah2'. A state of cessation of mental modifications or Chittavrttis due to mind, intellect and ego is yoga. Samyoge Yogalthyukthojeevatmaparamatmano' Yoga is the union of Jeevatma with Paramatma. In Ayurveda the term 'Yoga' is defined as 'Sukhadukhaanarambhadatmastheemanasi Sthire ${ }^{5}$. When manas is Sthira in Atma thereby there is no production of Sukha and Dukha, Vashitva of Shareera in Atma is attained which itself is Yoga.

Chittavrttis- Pramana, Viparyaya, Vikalpa, Smriti and Nidra ${ }^{6}$ In Yoga Satyajnana is gained through Pratyaksha, Anumana, Agama Pramanas ${ }^{7}$.In Ayurveda Pramana is the tool for Roga and Rogi Pareeksha ${ }^{8}$.
Pratyaksha, Anumana and Aptopadesha are accepted as valid examination procedures in Ayurvedic science. Viparyaya in Yoga Darshana mean Smithyajyana9 whereas in Ayurveda it is the reversed opinion or contradiction of the statement which is accepted. In Ayurveda Smruti is enumerated as one of the Lakshanas of Atma and also satva. If there is loss of Smruti, along with Dhi, Dhriti, then person does Prajnaparadha ${ }^{10}$.To examine Smritiacharyas have said that the 'memory is to be inferred by recollection'. In Yoga Darshana,

Nidra is responsible for the Abhava of Samanyajnana and in Ayurveda it results in increase of strength, longevity etc ${ }^{11}$. If person doesn't sleep properly, he will suffer from disease, loss of strength and even hemay get death $^{12}$.

\section{Nirodhaof ChittaVrtti}

In Yoga, Nirodha of Chittavrttis is attained through Abhyasa (trying to be in the stiti of chitta) and

Vairagya. In Ayurveda Abhyasa is Sheelanamsatatakriya (continuous practice).

Panchaklesha - Avidya, Asmita, Raga, Dvesha, Abhinivesha

In Yoga- Avidya is the basic cause for all Kleshas. Understanding of Nityaasanitya, Suchiasashuci and Sukhaas Dukha. Raga is lobha or greed towards $\mathrm{Su}$ khotpadakavastu. Dveshais the of Dukha in the form of Virodha and Krodha. Abhinivesha is fear of death and attachment towards life. In Ayurveda Vidya is considered as one of the Vaidya guna. Acharyas have mentioned Ragaas Kama, Dweshaas Apriti and Tiraskara, Abhinivesa as nischaya.

\section{Application of Ashtangasof Yoga}

Yama and Niyamas are mentioned in Ayurveda in the context of Sadvruttaand Achararasayana in order to improve the mental health. While describing about the ways of getting salvation, it has been told that one should have confidence in Yogic practices ${ }^{13}$. Asanas are adopted in Ayurveda for different treatment procedures that which is Sukha i.e. comfortable postures. Here the explanation Sthiram Sukham Asanam mentioned 
For practicing Pranayama has not been adopted and elaborate descriptions of each Asanas is not given much importance. In Ayurveda, Pranayama is mentioned as a treatment for respiratory ailments ${ }^{14}$. The sense faculties to be concentrated in the mind, the mind in soul, and the self in himself (Niyamanam indriyanamcetasi, Cetasaatmani). Avoidance of attachment and hatred towards the objects of senses (Indriyartheshuanuragopatapahah). This stands for Pratyahara, Dharana and Samadhi. Samadhi is explained as one of the Manasarogachikitsa.

\section{Yoga and its relationship with Ayurveda}

Yoga and Ayurveda give us the tools to live according to our unique nature and its particular capacities. Both are designed to bring your individual constitution, both physically and psychologically, into balance and harmony. Vedic principles indicate that it is best to eat, and exercise based on your particular constitution. Therefore, Asana is best practiced and designed based on individual needs. Ayurveda focuses on the individual's constitution or body type which is referred to as Dosha

\section{Prakriti.}

Features of individuals from various Dosha Prakriti and imbalances in their mental temperament are discussed below in brief:

\section{Vata Prakriti ${ }^{15}$}

On the psychological level Vata constitution individuals will be easily susceptible to happiness, sorrow, grief, restless, active. They are emotionally sensitive and prone to fear and anxiety, fluctuating moods and opinions. With regard to Yoga, this constitution individuals like energy practices, like doing things, keep things moving, like to change things.

Pitta Prakriti ${ }^{15}$ : They are moderately active and cannot endure stressful activities, tendency to be angry on slight provocation, intelligent, strong opinions. This type individuals are often attracted to meditation and working on their mind. They are natural seekers and mentally strong.

Kapha Prakriti15: People of this constitution type are not as active as Vata and Pitta, has a good endurance to stress, emotional but with steady strong feelings, calm, loyal, content ed and consistent. Can become and suffer from too much attachment.

\section{Yog Asanas as per various Prakriti} Yoga postures for Vata Constitution

Vata predominant individuals should emphasize on calming, grounding, steady, strengthening, and balancing while doing their practice. Vinyasa or flow styles of yoga tend to move quickly from one pose to the next and can aggravate the hyper mobile quality of Vata. Vata people require gentle yoga procedures that do not exhaust them. They should follow any movement Asanas with longer periods of sitting postures. To control Vata they should practice Pranayama and meditation in those postures. Asanas Siddhasana, Vajrasana, Virasana, Vrkshasana, Virabhadrasana, Paschimottasana, Kurmasana, Naukasana ${ }^{16}$.

\section{Yoga postures for Pitta Constitution}

Pitta individuals should maintain a calm, cool and relaxed state of mind while doing Asanas. Asana practice tends to generate heat in the body, it is best to do them at cooling times of the day. Pittas should perform Asanas in a way that is cooling, nurturing, expansive and relaxing. Pittas are benefited by postures that aim at releasing tension from the mid abdomen, where Pitta accumulates. Forward bends are generally good for pitta because they bring more energy to the mid abdomen and have a cooling effect if done in gentle manner. Asanas- Trikonasana, Ardhachandrasana, Upavisthakonasana, Kurmasana, Paschimottasana, Ardhamatsyendrasana, Marichyasana ${ }^{16}$.

Yoga postures for Kapha Constitution Kapha types tend to be sedentary and seldom are physically active unless stimulated or prodded to do so. More active exercise is required for them, stimulating their metabolism and increasing circulation. Their practice should be energetic, warming, lightening, and stimulating. Vinyasa or flow style yogais good for Kapha individuals because it is dynamic and moves quickly from one poseto the next though not vigorous.

Asanas - Virabhadrasana, Utthita hastapadangushthasana, Ardhachandrasana, Adhomukhasvanasana, Urdhamukhasvanasana, Adhomukhavrksasana, Ustrasana, Mayurasana ${ }^{16}$. 


\section{DISCUSSION}

Yoga Darshana and Ayurveda both have their own principles governing the body. Ayurveda considers the Tridoshas (Vata, Pitta, Kapha) as the regulators of body and mind. Yoga Darshana though considers the Tridosha theory of Ayurveda, stresses on the fact that it is the Triguna s(Satva, Rajas, Tamas) which regulate each and every actions of the body in turn influencing Tridoshas also. Yoga Asanas and Pranayama are advocated for physical and mental health and there by contribute to Tridosha balance ensuring a healthy life. For meeting the objective Swasthya Rakshana and Vikaraprashama, Sthiratva of Shareer and Manas is needed which can be achieved by the practice of Asanas and Pranayama along with adopting Yama, Niyama for a complete physical, mental, social and spiritual wellbeing. Common psychological features associated with various constitution types described in Ayurveda and the role of specific Yog Asanas in regulating the psychology of an individual is discussed below.

\section{CONCLUSION}

Yoga and Ayurveda aims at moksha Prapti by Atyantadukhanivrutti. As they are contemporary sciences the influence of Yoga is much seen in Ayurveda and it is also directly mentioned by Acharya Caraka. The thoughts of yogic philosophies are considered fundamental steps to raise to the height of super consciousness when all miseries vanish. Most of the concepts of Yoga are accepted as such some are modified for the medical science. It is important to integrate Yoga and Ayurveda in order to bring out a complete holistic healing system. Integrating Yoga with Ayurveda adds a spiritual and psychological dimension to Ayurvedic treatment modalities, without which Ayurveda tends to become a mere physical model devoid of spiritual and Vedic healing powers. Application of the concepts of yoga in conjunction with Ayurveda enhances the therapeutic application of both the contemporary systems of healing. Ayurveda provides the appropriate lifestyle recommendations for Yoga practice, as well as the background to unfold the full healing potential of all aspects of Yoga. Yoga provides the spiritual and psy- chological basis for Ayuveda and its higher applications.

\section{REFERENCES}

1. Acharya JT, Charaka Samhita with Ayurveda Dipika commentary of Chakrapani Datta, $5^{\text {th }}$ ed. (Chaukambha Sanskrit Sansthan), (2001) p.187.

2. Rao V M, The essence of Yoga, (Chaukhambha Orientalia), (2011) p.2.

3. Acharya Shukla Vidyadhar, Charaka Samhita of Agnivesa, (Chaukhamba Sanskrit Pratishthan), p.638.

4. Acharya JT, Susrutha Samhita with Nibandhasangraha commentary of Dalhanacharya, (Chaukambha Surbharati Prakashan), (2003) p.75.

5. Acharya JT, Charaka Samhita with Ayurveda Dipika commentary of Chakrapani Datta, 5thed. (Chaukambha Sanskrit Sansthan), (2001) p.300.

6. Rao V M, The essence of Yoga, (Chaukhambha Orientalia), (2011) p.2.

7. Acharya JT, Charaka Samhita with Ayurveda Dipika commentary of Chakrapani Datta, $5^{\text {th }}$ ed. (Chaukambha Sanskrit Sansthan), (2001) p.247.

8. Acharya JT, CharakaSamhita with Ayurveda Dipika commentary of Chakrapani Datta, 5thed. (Chaukambha Sanskrit Sansthan), (2001) p.247.

9. Rao V M, The essence of Yoga, (Chaukhambha Orientalia), (2011) p.2.

10. Acharya JT, Charaka Samhita with Ayurveda Dipika commentary of Chakrapani Datta, 5thed. (Chaukambha Sanskrit Sansthan), (2001) p.297.

11. Acharya Harisastri Paradakara, Astanga Hrdayam with Sarvangasundara and Ayurvedarasayana commentary of Arunadatta and Hemadri, 9thed. (Chaukambha Orientalia), (2005) p.140.

12. Acharya Harisastri Paradakara, Astanga Hrdayam with Sarvangasundara and Ayurvedarasayana commentary of Arunadatta and Hemadri, 9thed. (Chaukambha Orientalia), (2005) p.140.

13. Acharya JT, Charaka Samhita with Ayurveda Dipika commentary of Chakrapani Datta, 5thed. (Chaukambha Sanskrit Sansthan), (2001) p.300.

14. Acharya JT, Susrutha Samhita with Nibandhasangraha commentary of Dalhanacharya, (Chaukambha Surbharati Prakashan), (2003) p.759.

15. Acharya JT, Caraka Samhita with Ayurveda dipika commentary of Chakrapanidutta, Reprint ed. (Chaukambha Orientalia), (2011), p.277. 
16. David Frawley, Yoga and Ayurveda self-healing and self-realization, (Motilal Banaras), (2002) pp.223-225.

\section{Source of Support: Nil}

\section{Conflict of Interest: None Declared}

How to cite this URL: Kankre Rameshwari et al: A Comparison Of Brihattrayee And Yogic Darshana. International Ayurvedic Medical Journal \{online\} 2021 \{cited March, 2021\} Available from: http://www.iamj.in/posts/images/upload/615 619.pdf 